\title{
Thermal Annealing and Phase Transformation of Serpentine-Like Garnierite
}

\author{
Arun Kumar ${ }^{1,2} \oplus$, Michele Cassetta ${ }^{1}$, Marco Giarola ${ }^{3}$, Marco Zanatta ${ }^{4} \oplus$, Monique Le Guen ${ }^{5}$, \\ Gian Domenico Soraru ${ }^{6}$ and Gino Mariotto ${ }^{1, *} *$ (D)
}

1 Department of Computer Science, University of Verona, 37134 Verona, Italy; arun.kumar@mdm.imm.cnr.it (A.K.); michele.cassetta@univr.it (M.C.)

2 CNR-Institute for Microelectronics and Microsystems, Agrate Brianza, 20864 Agrate, Italy

3 Centro Piattaforme Tecnologiche (CPT), University of Verona, 37134 Verona, Italy; marco.giarola@univr.it

4 Department of Physics, University of Trento, 38123 Povo, Italy; marco.zanatta@unitn.it

5 Innovation Technology Direction, ERAMET IDEAS, 78190 Trappes, France; monique.le-guen@eramet.com

6 Department of Industrial Engineering, University of Trento, 38123 Povo, Italy; soraru@ing.unitn.it

* Correspondence: gino.mariotto@univr.it

check for updates

Citation: Kumar, A.; Cassetta, M.; Giarola, M.; Zanatta, M.; Le Guen, M.; Soraru, G.D.; Mariotto, G. Thermal Annealing and Phase Transformation of Serpentine-Like Garnierite. Minerals 2021, 11, 188. https:// doi.org/10.3390/min11020188

Academic Editor: Basilios Tsikouras

Received: 4 January 2021

Accepted: 9 February 2021

Published: 11 February 2021

Publisher's Note: MDPI stays neutral with regard to jurisdictional claims in published maps and institutional affiliations.

Copyright: (c) 2021 by the authors. Licensee MDPI, Basel, Switzerland. This article is an open access article distributed under the terms and conditions of the Creative Commons Attribution (CC BY) license (https:/ / creativecommons.org/licenses/by/ $4.0 /)$.

\begin{abstract}
This study is focused on the vibrational and microstructural aspects of the thermally induced transformation of serpentine-like garnierite into quartz, forsterite, and enstatite occurring at about $620{ }^{\circ} \mathrm{C}$. Powder specimens of garnierite were annealed in static air between room temperature and $1000{ }^{\circ} \mathrm{C}$. The kinetic of the transformation was investigated by means of thermogravimetric and differential thermal analysis, and the final product was extensively characterized via micro-Raman spectroscopy and X-ray diffraction. Our study shows that serpentine-like garnierite consists of a mixture of different mineral species. Furthermore, these garnierites and their composition can provide details based on the mineralogy and the crystalline phases resulting from the thermal treatment.
\end{abstract}

Keywords: garnierite; phase transformation; TGA/DSC; XRD; micro-Raman spectroscopy

\section{Introduction}

In 1863, Jules Garnier discovered a nickel ore in New Caledonia, a magnesium-based nickel silicate later named garnierite [1]. This rock is mined from laterite deposits, and it is formed by weathering and secondary mineralization of igneous ultra-mafic rocks. Garnierite is classified as a hydrous Ni-Mg-phyllosilicate [2-4]. However, the identification of the garnierite minerals composition is a well-known open problem $[1,5,6]$, as these minerals are poorly crystalline, naturally fine-grained, inhomogeneously distributed, and frequently consist of mixtures of serpentines, talc, chlorite, sepiolite, and smectite. Nickel is prevalently hosted in serpentine-like, talc-like, or clay-like phases [7,8]. For instance, in Nibearing serpentines, it has been shown that $\mathrm{Ni}^{2+}$ can substitute for $\mathrm{Mg}^{2+}$ in the serpentine mineral lizardite, since the two cations have similar ionic radii $[2,7]$. The global request of nickel for industrial and technological application makes the study of possible sources as garnierite ores extremely interesting [1]. Since the garnierite mineral are a mixture of hydrous silicates, the phase occurrence will depend on the distribution of nickel inside the mineral, and each phase transforms independently. Thus, the thermal transformations of garnierite are of interest for studying the primary nature of the minerals $[9,10]$. Furthermore, the thermal decomposition of these hydrous silicates provides insight about the thermal stability of garnierite. This is an important tool for the assessment of these types of materials in terms of mineral chemistry and sheds light on the amount of water on their structure [5], which has been confirmed as very insightful for differentiating among the serpentine minerals $[5,9,10]$.

In this study, thermal analysis has been applied to study the structural transformation of garnierite powder, whose mineralogy was extensively characterized by means of 
X-ray diffraction (XRD) and micro-Raman spectroscopy. In particular, micro-Raman spectroscopy constitutes a very powerful and non-invasive tool for the identification of mineral phases in geological samples, as well as for the characterization of the heterogeneous materials [11-14]. Here, micro-Raman spectroscopy has been employed to investigate both the serpentine-like garnierite and its phase transformation under thermal treatment, which is not reported in previous studies as per the best of our knowledge.

\section{Materials and Methods}

A garnierite sample coming from a mine of New Caledonia was provided by ERAMET IDEAS within the EU-H2020 SOLSA project grant no. 689868 (http:/ / www.solsa-mining. eu), which was funded within the EU-H2020 Raw Material program. The sample was a quite hard and compact dark grayish rock with white veins, of irregular form, and some $\mathrm{cm}$ in size. An optical image is shown in Figure 1 (leftmost image). For the thermal treatment, some pieces of the garnierite sample were manually ground with a pestle in a mortar, thus obtaining a fine brown powder (rightmost image in Figure 1). The elemental composition of this pristine powder was determined by an environmental scanning electron microscope (ESEM) coupled with an energy-dispersive X-ray (EDX) analyzer. Both elemental spectrum and elemental composition are shown in Figure S1 and in Table S1, respectively (Supplementary Materials).

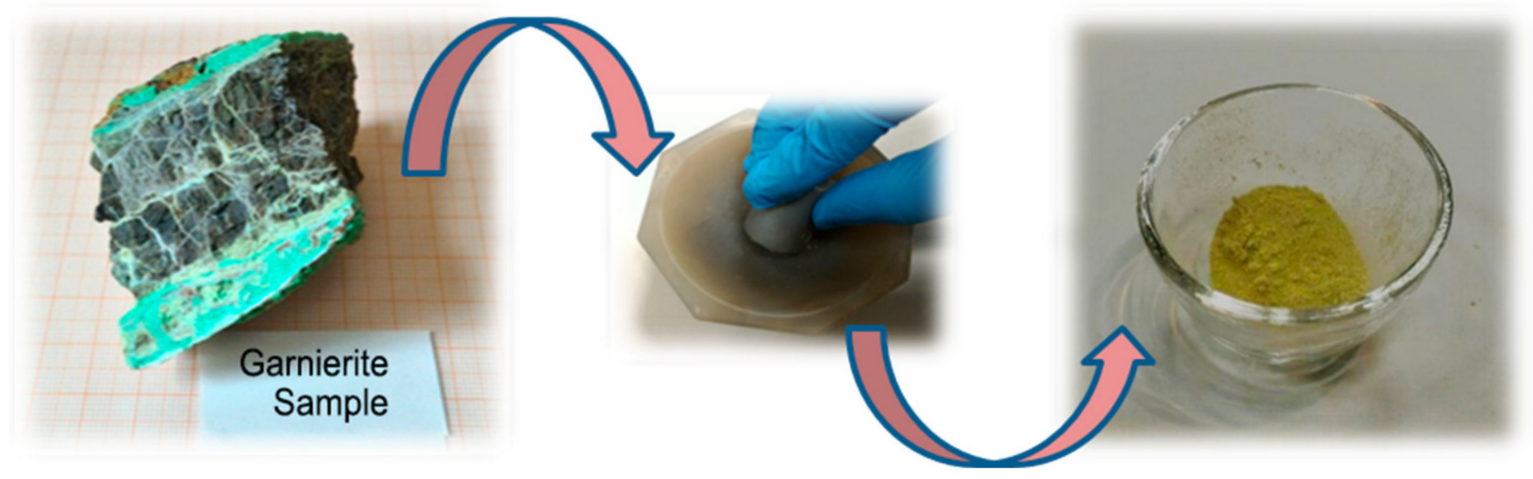

Figure 1. Optical image of the starting garnierite sample (left image); small pieces of this sample were manually ground (central image) to obtain the fine powder used in the thermal treatment (right image).

The thermal stability of the garnierite powder sample was investigated by thermogravimetric analysis (TGA) and differential thermal analysis (DTA) using an STA 449C Jupiter $^{\circledR}$ analyzer (Netzsch-Gerätebau $\mathrm{GmbH}$, Selb, Germany) from room temperature to $1000{ }^{\circ} \mathrm{C}$ at a heating rate of $5{ }^{\circ} \mathrm{C} \mathrm{min}-1$ and a static air flux of $40 \mathrm{ml} \mathrm{min}{ }^{-1}$. For TGA, $50 \mathrm{mg}$ garnierite powder was measured along with a reference sample of aluminum powder.

Micro-Raman spectra were acquired in backscattering geometry with a Horiba Jobin Yvon LabRAM HR800 spectrometer equipped with a $632.8 \mathrm{~nm}$ He-Ne laser and an optical microscope (Olympus, BX41). The laser beam was spatially filtered by a $75 \mu \mathrm{m}$ pinhole and focused onto the sample surface by a long working distance (LWD) $80 \times$ objective having $0.75 \mathrm{NA}$. This yielded to a spatial resolution of about $1 \mu \mathrm{m}$ with an irradiation power at the sample surface of $1.5 \mathrm{~mW}$. The scattered light was analyzed using a 600 lines $/ \mathrm{mm}$ grating and collected by a Si-based CCD (charge-coupled device) detector of $1024 \times 256$ pixels cooled with liquid nitrogen. A composite spectrum covering the spectral range between 150 and $4000 \mathrm{~cm}^{-1}$ was obtained by using the LabSpec (version 5) package that merges several partial spectra with different wavenumber ranges. Before the measurements, the spectrometer was calibrated using the $520.4 \mathrm{~cm}^{-1}$ peak of crystal Si.

XRD measurements were acquired with a Thermo ARL X'TRA powder diffractometer, operating in the Bragg-Brentano geometry and equipped with a $\mathrm{Cu}$-anode $\mathrm{X}$-ray source $\left(\mathrm{K}_{\alpha}, \lambda=1.5405 \AA\right)$, using a Peltier $\mathrm{Si}(\mathrm{Li})$ cooled solid-state detector. The patterns were 
collected with a scan step of $0.03^{\circ}$ in the $10-702 \theta$ range. The diffractometer was calibrated with a reference silicon powder $\left(\mathrm{d}_{111}=3.1353 \AA\right)$.

\section{Results and Discussion}

The starting garnierite sample was extensively characterized by means of micro Raman spectroscopy. In particular, measurements were acquired along the gray veins (see Figure 1) correlating the sample surface texture shown by the microscopic image with the mineral phases revealed by the Raman spectra. Three typical results for such an analysis are reported in Figure 2 for the three major mineral phases, i.e., the quartz and two hydrous Mg-Ni silicates. In the Raman spectra, we highlighted the low wavenumber (150-1100 $\mathrm{cm}^{-1}$ ) and the high-wavenumber $\left(3550-3950 \mathrm{~cm}^{-1}\right)$ regions: the first contains the vibrational fingerprints of the mineral species, while the second displays the bands of the structural water, which is pivotal to identify the serpentine forms.
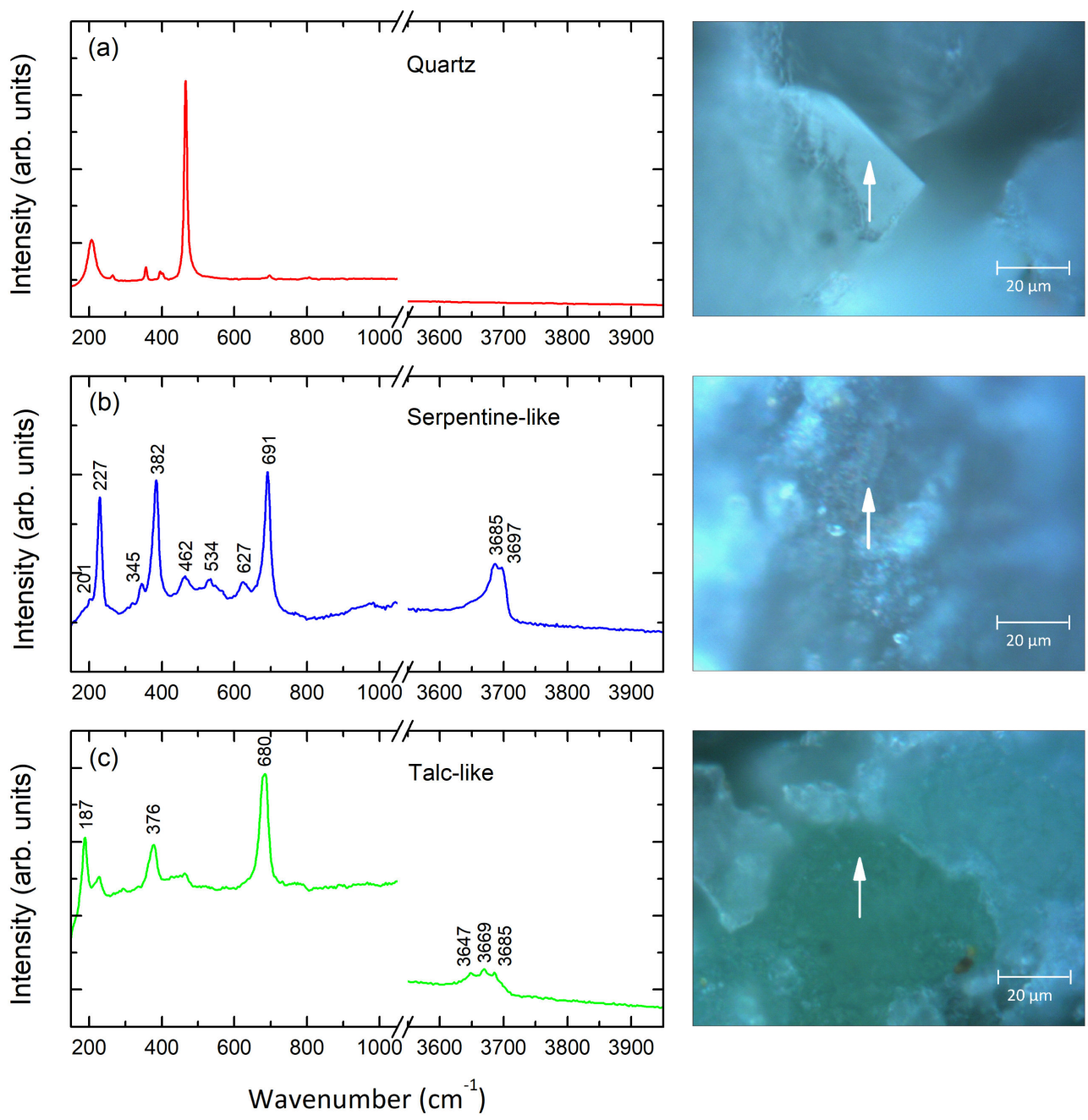

Figure 2. Typical Raman spectra of (a) quartz, (b) serpentine-like, and (c) talc-like mineral phases acquired on the garnierite sample. The microscopic images on the right show the sampled area marked by the white arrow. Both Raman spectra and optical images were acquired with an $80 \times$ LWD objective.

As already mentioned, quartz is one of the major phases detected. Its Raman spectrum is displayed in Figure 2a: the fingerprints of the quartz are a strong narrow peak at $464 \mathrm{~cm}^{-1}$ together with a band centered at about $207 \mathrm{~cm}^{-1}$ and a small peak occurring at about $356 \mathrm{~cm}^{-1}$ [15-17]. Figure $2 \mathrm{~b}$ shows the typical Raman spectrum of serpentine-like garnierites (Ni-Serpentine), which is characterized by strong Raman bands at about 227, 
382 , and $691 \mathrm{~cm}^{-1}$. The peaks at about 227 and $382 \mathrm{~cm}^{-1}$ can be assigned either to minerals of the serpentine group or to talc. These peaks are less intense (or even absent) when the garnierite contains high amounts of kerolite-pimelite [18]. We can say that a low amount talc-like phase is also present in the pristine garnierite ore. In the literature, the band at $227 \mathrm{~cm}^{-1}$ is attributed to either metal-oxygen [17] or O-H-O vibrations [19,20]; whereas the peaks at about $345 \mathrm{~cm}^{-1}$ and $382 \mathrm{~cm}^{-1}$ are due to metal-oxygen [18], $\mathrm{SiO}_{4}$ bending/symmetric $[19,20]$, and the one at about $689 \mathrm{~cm}^{-1}$ to Si-O vibrations [19-21], in all serpentine minerals. Finally, Figure $3 \mathrm{~b}$ shows the spectrum of talc with a strong band peaked at about $680 \mathrm{~cm}^{-1}$, but the other intense bands shown by Ni-serpentine are absent. In contrast, it shows intense bands at around $187 \mathrm{~cm}^{-1}$ and a strong peak at $376 \mathrm{~cm}^{-1}$.

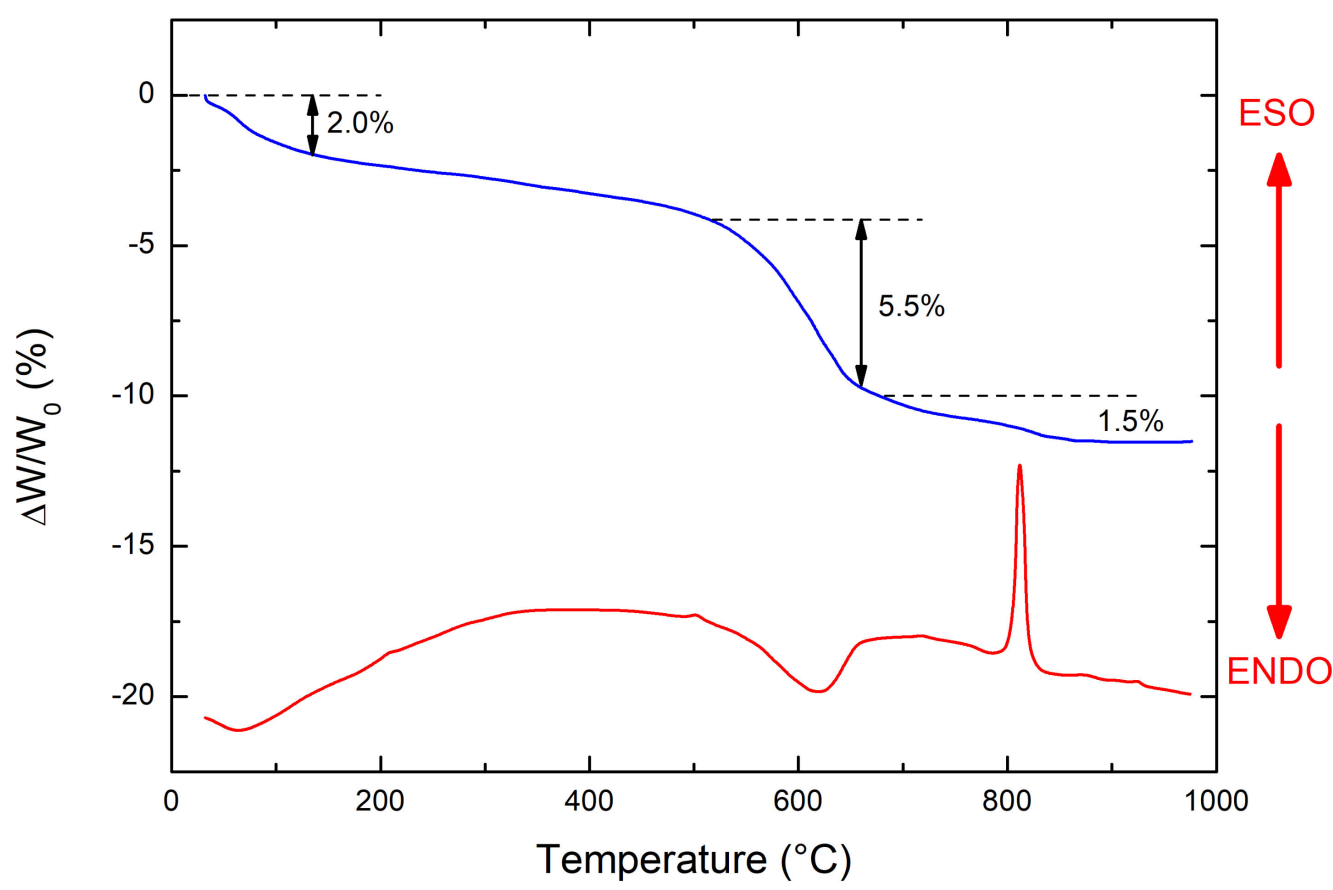

Figure 3. Thermogravimetric analysis (TGA) (in blue and differential thermal analysis (DTA) (in red) curves of the pristine garnierite powder sample.

The spectra of both the garnierite types show a feature due to Si-O vibrations. However, while in serpentine-like garnierite, it is a strong peak at about $691 \mathrm{~cm}^{-1}$, in the talk-like one, it appears to have a band at about $680 \mathrm{~cm}^{-1}$. Therefore, this difference can be used to discriminate between the two species [19-23]. Raman spectra are also sensitive to the effect of the Ni content in Ni-bearing phyllosilicates. As a matter of fact, the effect of the cations in the octahedral site and the Raman band positions below $600 \mathrm{~cm}^{-1}$ in phyllosilicates are well discussed in the literature [24]. However, this effect is small, and upon comparing the spectra of garnierite and Ni-free serpentine or talc ones, no significant differences were observed at low frequency [5]. Conversely, the spectral region above $3500 \mathrm{~cm}^{-1}$ provides very interesting structural insights about the serpentine minerals. In fact, serpentine-like garnierite shows a broad spectral feature consisting of a strong band centered at about $3685 \mathrm{~cm}^{-1}$ and of a pronounced shoulder peaked at $3697 \mathrm{~cm}^{-1}$; see Figure $2 \mathrm{~b}$. In talc-like garnierite, a broader feature, consisting of three spectral components, peaked at about 3647, 3669 , and $3685 \mathrm{~cm}^{-1}$ respectively, is observed; see Figure 2c. All these bands are often assigned in the literature to $\mathrm{O}-\mathrm{H}$ stretching or $\mathrm{OH}$ vibration of phyllosilicates [21-27]. The number and types of $\mathrm{O}-\mathrm{H}$ sites and the types of cation occupancies around $\mathrm{O}-\mathrm{H}$ groups control the number of $\mathrm{O}-\mathrm{H}$ peaks, their positions, and their relative intensities [24].

Figure 3 shows the thermal analysis on garnierite powder with the results of the TGA (blue line) and DTA (red line). Considering the TGA results, this garnierite sample shows that we detect three distinct weight loss steps. The first one is a continuous weight loss 
of about $2 \%$, going from room temperature up to $500{ }^{\circ} \mathrm{C}$. Conversely, the second step is a well-defined weight loss of about $5.5 \%$ at $620{ }^{\circ} \mathrm{C}$ and corresponds to an endothermic peak in the DTA curve. Finally, the third weight loss is of about $1.5 \%$ and occurs at $813^{\circ} \mathrm{C}$, and it is accompanied by a strong exothermic peak in the DTA. Several studies performed on Ni-rich garnierite veins $[7,28]$ have displayed that optimum temperatures of dihydroxylation of the layered silicates occur at $560-645^{\circ} \mathrm{C}$ for the $7 \AA$ - type, which match with serpentine-like mineral. The same authors propose that dihydroxylation taking place in the range of $815-825^{\circ} \mathrm{C}$ can be assigned to the $10 \AA$-type, which matches with serpentine + talc-like minerals. Consequently, the endothermic peak at $620^{\circ} \mathrm{C}$ can be assigned to the de-hydroxylation of the $\mathrm{Ni}$ incapacitated serpentine. Increasing the temperature, the anhydrous serpentine-like garnierite breaks down, and the exothermic at $813^{\circ} \mathrm{C}$ can be ascribed to the formation of anhydrous silicates crystals such as olivine and enstatite.

Furthermore, the well-established mechanisms of thermal transformation for the equilibrium of serpentine and talc $[9,28-30]$ are shown below:

$$
\begin{aligned}
& \mathrm{Mg}_{3} \mathrm{Si}_{2} \mathrm{O}_{5}(\mathrm{OH})_{4}=\mathrm{Mg}_{2} \mathrm{SiO}_{4}+\mathrm{MgSiO}_{3}+2 \mathrm{H}_{2} \mathrm{O} \\
& \text { serpentine olivine enstatite } \\
& \mathrm{Mg}_{3} \mathrm{Si}_{2} \mathrm{O}_{5}(\mathrm{OH})_{4}=(3 / 2) \mathrm{Mg}_{2} \mathrm{SiO}_{4}+(1 / 2) \mathrm{SiO}_{2}+2 \mathrm{H}_{2} \mathrm{O} \\
& \text { serpentine olivine quartz } \\
& \mathrm{Mg}_{3} \mathrm{Si}_{4} \mathrm{O} 10(\mathrm{OH})_{2}=3 \mathrm{MgSiO}_{3}+\mathrm{SiO}_{2}+\mathrm{H}_{2} \mathrm{O} \text {. } \\
& \text { talc enstatite }
\end{aligned}
$$

It was shown that up to $900{ }^{\circ} \mathrm{C}$, serpentine mainly transforms into olivine, while serpentine-like garnierite with low Ni content turns into olivine and possibly also into enstatite, as shown in Equation (1). However, if the content of $\mathrm{Ni}$ is high, it transforms into two main phases, olivine (forsterite) and quartz, as shown in Equation (2). Furthermore, for talc-like garnierite, with low $\mathrm{Ni}$ content, the phase transformation gives rise to enstatite, as shown in Equation (3), whereas with high Ni content, it transforms into olivine phase up to the same range of temperature. Consequently, the identification of the mineral composition of the treated powder can shed some light on the nature of our garnierite.

The above-mentioned phase transformation scenario was confirmed by XRD and micro-Raman on treated powders.

Figure 4 shows the XRD pattern of the garnierite powder before and after the thermal treatment. As expected, the pristine garnierite powder is heterogeneous, and it mainly consists of quartz. The XRD pattern of quartz shows the major diffraction peaks at about $20.77^{\circ}, 26.55^{\circ}, 36.47^{\circ}, 39.37^{\circ}, 42.37^{\circ}, 50.04^{\circ}$, and $59.84^{\circ}$ (degrees) having d-spacing of 4.27 , $3.35,2.46,2.28,2.13,1.82$, and $1.54 \AA$ respectively, which are in good agreement with the RRUFF database [31]. The diffraction peak at $2 \theta=12.01^{\circ}$ shows that the main Ni-bearing mineral phase is serpentine $\left[\left(\mathrm{Mg}, \mathrm{Fe}, \mathrm{Ni}_{6} \mathrm{Si}_{4} \mathrm{O}_{12}(\mathrm{OH})_{6}\right]\right.$ having $d_{101}=7.36 \AA[7,32,33]$. Other broad peaks at about $19.55^{\circ}, 24.44^{\circ}, 34.43^{\circ}$, and $35.57^{\circ}$ having d-spacing $4.53,3.63$, 2.60 , and $2.52 \AA$, respectively, belong to serpentine or the talc-like garnierite phase [34,35]. These broad peaks could be due to the intermixing of talc and quartz phases. XRD results reveal that the diffraction peaks of serpentine-like garnierite dominate over the quartz peaks with respect to the Ni content. 


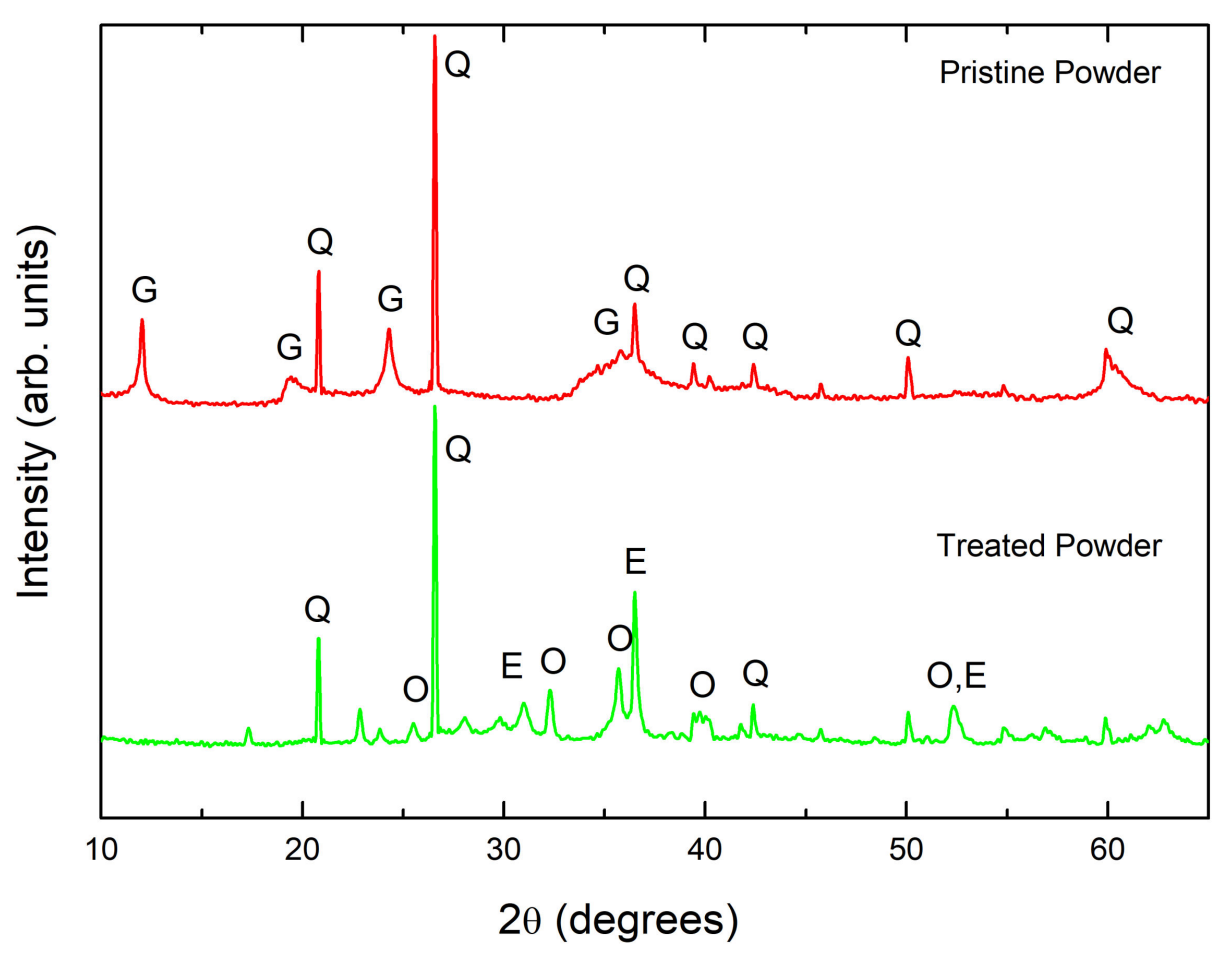

Figure 4. XRD patterns of garnierite powder before (red line) and after (green line) the thermal treatment. The Bragg peaks of the different minerals are labeled with $\mathrm{G}$ (garnierite), $\mathrm{Q}$ (quartz), $\mathrm{O}$ (olivine), and E (enstatite).

After the thermal treatment, the XRD pattern still shows the presence of quartz peaks that progressively become sharper and better defined. Another major change observed is the degradation of the Bragg peaks of serpentine minerals at about $36^{\circ}, 42^{\circ}$, and $52.2^{\circ}$ and their replacement by small reflections or shoulders. Specifically, the sharp overlapping reflections originating from the broad band at about $2 \theta=36.2^{\circ}$ for the untreated mixed serpentines (i.e., $2.45 \AA$ for chrysotile-2M, $2.51 \AA$ for lizardite-1T, and $2.55 \AA$ for antigorite) tend to wane and be replaced by a broad two-dimensional diffraction band of olivine (forsterite) and enstatite (see Figure 4), indicating a high degree of stacking disorder in silicate layers $[28,30,32,33]$. These results indicate that the phase transformation of the garnierite to the olivine (forsterite) and enstatite has occurred and they are in good agreement with the previously reported literature $[9,30]$.

The phase transformation from garnierite to olivine (forsterite) and enstatite is also evidenced by micro Raman spectroscopy; see Figure 5. In order to identify the mineral phases, the recorded Raman spectra were compared to reference spectra from both the RRUFF database [31,36,37] and the Raman Open Database [38-41]. An extensive sampling showed mostly quartz $\left(\alpha-\mathrm{SiO}_{2}\right)$ with inclusions of forsterite, $\mathrm{Mg}_{2}\left(\mathrm{SiO}_{4}\right)$, and micro-segregation of enstatite $\left(\mathrm{MgSiO}_{3}\right)$. 

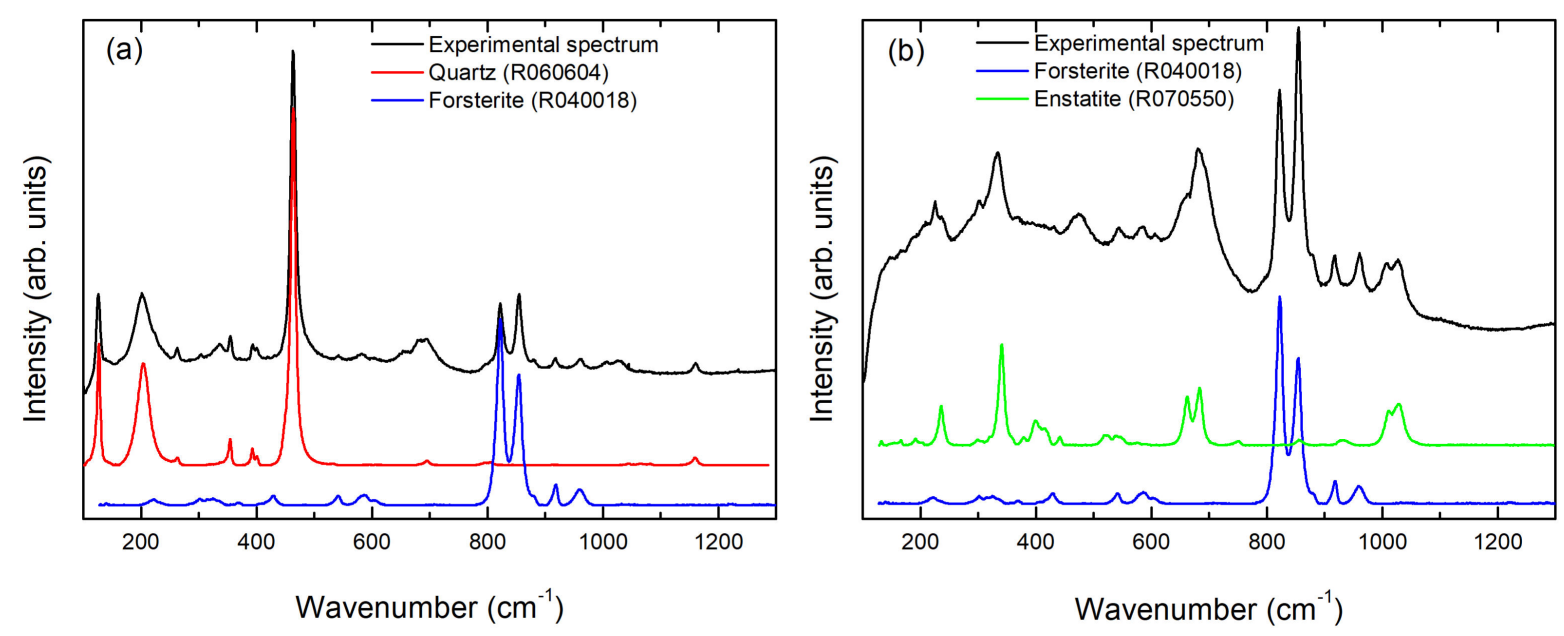

Figure 5. Typical Raman spectra of the thermally treated garnierite powder (black lines), (a) quartz and forsterite, and (b) forsterite and enstatite. The reference spectra used for the identification of the phases. Colors are described in the legend; reference spectra are from the RRUFF database.

Figure 5a shows a typical experimental spectrum resultin $\mathrm{g}$ from the supeposition of quartz, as main crystalline phase present, with forsterite, in the form of inclusions.

Indeed, in addition to the typical quartz features, at 127, 203, and $464 \mathrm{~cm}^{-1}$, the two Raman bands at about 822 and $854 \mathrm{~cm}^{-1}$ are the fingerprints of forsterite, and they are due the $\mathrm{Si}-\mathrm{O}$ symmetric and the $\mathrm{Si}-\mathrm{O}$ antisymmetric stretching band, respectively [42-44]. In addition to these two main peaks other less intense Raman bands in forsterite occur at approximately $224,303,433,542,582,603,881$, and $962 \mathrm{~cm}^{-1}$.

In some cases, besides these typical phases, the occurrence of enstatite was also detected. This is the case of Figure $5 b$, where the contribution of forsterite is dominant but enstatite is clearly present. The characteristic bands of enstatite are peaked at about 343, 662 , and $684 \mathrm{~cm}^{-1}[45,46]$. In general, Raman spectra recorded from the treated powders show the co-existence of two or more phases, which turn out in fair agreement with those detected by XRD.

\section{Conclusions}

In conclusion, if we combine the results of the thermal analysis and the phase characterization of the treated powder, we can assess the nature of the starting garnierite sample. Indeed, combining our results, we demonstrate that our material is basically serpentine-like garnierite with low Ni contents, which upon thermalization up to $900{ }^{\circ} \mathrm{C}$ transforms into olivine (forsterite) with a small segregation of enstatite. Furthermore, we can also infer that the low amount talc-like phase is present in the pristine garnierite ore. Thermogravimetric analysis proves there are at least three decomposition steps attributed to dehydration, dihydroxylation, and decomposition of the formed phases. The mechanism for the thermal decomposition of garnierite is highlighted. Serpentine-like garnierite transforms between 800 and $1000{ }^{\circ} \mathrm{C}$, depending on its $\mathrm{NiO}$ content. Serpentine-like garnierite, with low $\mathrm{NiO}$ content, transforms mainly to an olivine phase. Consequently, the formation of olivine and enstatite as a result of the thermal annealing of garnierite is supported both by XRD and micro Raman spectroscopy results. These results may help identify mixed crystalline phases in the initial garnierite ores. Such an approach can also help in geometallurgy, to study the transformations of mineral phases in a furnace during a pyrometallurgical process.

Supplementary Materials: The following are available online at https:/ /www.mdpi.com/2075-1 63X/11/2/188/s1, Figure S1: EDX spectrum of the pristine garnierite powder, Table S1: Average elemental content of the pristine garnierite powder used in this study. 
Author Contributions: Conceptualization, A.K. and M.Z.; methodology, A.K.; validation, A.K., M.Z. and G.M.; XRD, M.G.; TGA/DSC, G.D.S.; writing—original draft preparation, A.K.; writing-review and editing, M.C.; project administration, M.L.G.; supervision, G.M. All authors have read and agreed to the published version of the manuscript.

Funding: The 'SOLSA' project has received funding from the European Union's Horizon 2020 research and innovation program under grant agreement No. 689868.

Institutional Review Board Statement: Not applicable.

Informed Consent Statement: Not applicable.

Data Availability Statement: Not applicable.

Conflicts of Interest: The authors declare no conflict of interest.

\section{References}

1. Jun-Hui, X.; Ding, W.; Peng, Y.; Chen, T.; Zou, K.; Wang, Z. Extraction of Nickel from Garnierite Laterite Ore Using Roasting and Magnetic Separation with Calcium Chloride and Iron Concentrate. Minerals 2020, 10, 352. [CrossRef]

2. Qu, T.; Tian, Y.; Yang, B.; Liu, D.C.; Xu, B.Q.; Dai, Y.N. Study on the thermodynamic and experimental carbothermic reduction of garnierite. In Magnesium Technology; Wiley: Hoboken, NJ, USA, 2012; pp. 505-510. ISBN 9781118291214.

3. De Bakker, J.; Peacey, J.; Davis, B. Thermal decomposition studies on magnesium hydroxychlorides. Can. Metall. Q. 2012, 51, 419-423. [CrossRef]

4. Mongelli, G.; Taghipour, B.; Sinisi, R.; Khadivar, S. Mineralization and element redistribution in the Chah-Gheib Ni-laterite ore zone, Bavanat, Zagros Belt, Iran. Ore Geol. Rev. 2019, 111, 102990. [CrossRef]

5. Villanova-de-Benavent, C.; Jawhari, T.; Roqué-Rosell, J.; Galí, S.; Proenza, J.A. Ni-bearing phyllosilicates ("garnierites"): New insights from thermal analysis, $\mu$ Raman and IR spectroscopy. Appl. Clay Sci. 2019, 175, 47-66. [CrossRef]

6. Cathelineau, M.; Quesnel, B.; Gautier, P.; Boulvais, P.; Couteau, C.; Drouillet, M. Nickel dispersion and enrichment at the bottom of the regolith: Formation of pimelite target-like ores in rock block joints (Koniambo Ni deposit, New Caledonia). Miner. Deposita 2015, 51, 271-282. [CrossRef]

7. Wells, M.A.; Ramanaidou, E.R.; Verrall, M.; Tessarolo, C. Mineralogy and crystal chemistry of "garnierites" in the Goro lateritic nickel deposit, New Caledonia. Eur. J. Miner. 2009, 21, 467-483. [CrossRef]

8. Brindley, G.W.; Maksimovic, Z. The nature andnomenclature of hydrous nickel-containing silicates. Clay. Miner. 1974, 10, $271-277$. [CrossRef]

9. Hang, P.T.; Brindley, G.W. The nature of garnierites-III thermal transformations. Clays Clay Miner. 1973, 21, 51-57. [CrossRef]

10. Sazama, U.; Reller, A. The thermochemical reactivity of silicate minerals in hydrogen and methane. J. Therm. Anal. Calorim. 1996, 47, 357-364. [CrossRef]

11. Duée, C.; Maubec, N.; Laperche, V.; Capar, L.; Bourguignon, A.; Bourrat, X.; Yassine, B.; Mendili, E.; Chateigner, D.; Gascoin, S.; et al. Combined mineralogy and chemistry on drill cores: Challenging for on-line-real-time analyses. In Proceedings of the 14th Biennial SGA Meeting, Québec City, QC, Canada; 2017; Volume 3, pp. 1241-1244.

12. Secchi, M.; Zanatta, M.; Borovin, E.; Bortolotti, M.; Kumar, A.; Giarola, M.; Sanson, A.; Orberger, B.; Daldosso, N.; Gialanella, S.; et al. Mineralogical investigations using XRD, XRF, and Raman spectroscopy in a combined approach. J. Raman Spectrosc. 2018, 49, 1023-1030. [CrossRef]

13. El Mendili, Y.; Chateigner, D.; Orberger, B.; Gascoin, S.; Bardeau, J.-F.; Petit, S.; Duée, C.; Le Guen, M.; Pilliere, H. Combined XRF, XRD, SEM-EDS, and Raman Analyses on Serpentinized Harzburgite (Nickel Laterite Mine, New Caledonia): Implications for Exploration and Geometallurgy. ACS Earth Space Chem. 2019, 3, 2237-2249. [CrossRef]

14. Duée, C.; Orberger, B.; Maubec, N.; Laperche, V.; Capar, L.; Bourguignon, A.; Bourrat, X.; El Mendili, Y.; Chateigner, D.; Gascoin, S.; et al. Impact of heterogeneities and surface roughness on PXRF, pIR, XRD and Raman analyses: Challenges for on-line, real-time combined mineralogical and chemical analyses on drill cores and implication for "high speed" Ni-laterite exploration. J. Geochem. Explor. 2019, 198, 1-17. [CrossRef]

15. Scott, J.F.; Porto, S.P.S. Longitudinal and Transverse Optical Lattice Vibrations in Quartz. Phys. Rev. 1967, 161, 903-910. [CrossRef]

16. Shapiro, S.M.; O'Shea, D.C.; Cummins, H.Z. Raman Scattering Study of the Alpha-Beta Phase Transition in Quartz. Phys. Rev. Lett. 1967, 19, 361-364. [CrossRef]

17. Schmidt, P.; Bellot-Gurlet, L.; Leá, V.; Sciau, P. Moganite detection in silica rocks using Raman and infrared spectros-copy. Eur. J. Mineral. 2014, 25, 797-805. [CrossRef]

18. Wang, A.; Freeman, J.J.; Jolliff, B.L. Understanding the Raman spectral features of phyllosilicates. J. Raman Spectrosc. 2015, 46, 829-845. [CrossRef]

19. Rinaudo, C.; Gastaldi, D.; Belluso, E. Characterization of chrysotile, antigorite and lizardite by ft raman spectroscopy. Can. Miner. 2003, 41, 883-890. [CrossRef]

20. Groppo, C.; Rinaudo, C.; Cairo, S.; Gastaldi, D.; Compagnoni, R. Micro-Raman spectroscopy for a quick and reliable identification of serpentine minerals from ultramafics. Eur. J. Miner. 2006, 18, 319-329. [CrossRef] 
21. Kloprogge, J.T.; Frost, R.L.; Rintoul, L. Single crystal Raman microscopic study of the asbestos mineral chrysotile. Phys. Chem. Chem. Phys. 1999, 1, 2559-2564. [CrossRef]

22. Blaha, J.J.; Rosasco, G.J. Raman microprobe spectra of individual microcrystals and fibers of talc, tremolite, and related silicate minerals. Anal. Chem. 1978, 50, 892-896. [CrossRef]

23. Rosasco, G.J.; Blaha, J.J. Raman Microprobe Spectra and Vibrational Mode Assignments of Talc. Appl. Spectrosc. 1980, 34, 140-144. [CrossRef]

24. Wang, A.; Freeman, J.; Kuebler, K.E. Raman Spectroscopic Characterization of Phyllosilicates. In Proceedings of the Lunar and Planetary Science XXXIII, Houston, TX, USA, 11-15 March 2002; p. 1374.

25. Auzende, A.-L.; Daniel, I.; Reynard, B.; Lemaire, C.; Guyot, F. High-pressure behaviour of serpentine minerals: A Raman spectroscopic study. Phys. Chem. Miner. 2004, 31, 269-277. [CrossRef]

26. Frost, R.L.; Reddy, B.J.; Dickfos, M.J. Raman spectroscopy of the nickel silicate mineral pecoraite-An analogue of chrysotile (asbestos). J. Raman Spectrosc. 2008, 39, 909-913. [CrossRef]

27. Cathelineau, M.; Caumon, M.-C.; Massei, F.; Brie, D.; Harlaux, M.; Michel, C. Raman spectra of Ni-Mg kerolite: Effect of Ni-Mg substitution on O-H stretching vibrations. J. Raman Spectrosc. 2015, 46, 933-940. [CrossRef]

28. Brindley, G.W. Kinetics and Mechanisms of Dehydration and Recrystallization of Serpentine-I. Clays Clay Miner. 1963, $12,35-47$. [CrossRef]

29. Brindley, G.W.; Thi Hang, P. The nature of garnierites-I structures, chemical compositions and color characteristics. Clays Clay Miner. 1973, 21, 19-26. [CrossRef]

30. Brindley, G.W.; Hayami, R. Mechanism of formation of forsterite and enstatite from serpentine. Miner. Mag. J. Miner. Soc. 1965, 35, 189-195. [CrossRef]

31. Quartz R060604-RRUFF Database: Raman, X-ray, Infrared, and Chemistry. Available online: https://rruff.info/quartz/display= default/R060604 (accessed on 21 November 2020).

32. Zevgolis, E.N.; Zografidis, C.; Perraki, T.; Devlin, E. Phase transformations of nickeliferous laterites during preheating and reduction with carbon monoxide. J. Therm. Anal. Calorim. 2009, 100, 133-139. [CrossRef]

33. Fritsch, E.; Juillot, F.; Dublet, G.; Fonteneau, L.; Fandeur, D.; Martin, E.; Caner, L.; Auzende, A.-L.; Grauby, O.; Beaufort, D. An alternative model for the formation of hydrous $\mathrm{Mg} / \mathrm{Ni}$ layer silicates ('deweylite' /'garnierite') in faulted peridotites of New Caledonia: I. Texture and mineralogy of a paragenetic succession of silicate infillings. Eur. J. Miner. 2016, 28, 295-311. [CrossRef]

34. Ovung, T.N.; Ray, J.; Ghosh, B.; Mandal, D.; Dasgupta, P.; Paul, M. Occurrence of népouite in the serpentinite of the Manipur ophiolite belt, Northeastern India: Implication for melt-rock interaction in a supra-subduction zone. J. Geol. Soc. India 2017, 90, 154-158. [CrossRef]

35. Fu, W.; Zhang, Y.; Pang, C.; Zeng, X.; Huang, X.; Yang, M.; Shao, Y.; Lin, H. Garnierite mineralization from a serpentinite-derived lateritic regolith, Sulawesi Island, Indonesia: Mineralogy, geochemistry and link to hydrologic flow regime. J. Geoc. Explor. 2018, 188, 240-256. [CrossRef]

36. Forsterite R040018—RRUFF Database: Raman, X-ray, Infrared, and Chemistry. Available online: https://rruff.info/forsterite/ display=default/R040018 (accessed on 21 November 2020).

37. Enstatite R070550—RRUFF Database: Raman, X-ray, Infrared, and Chemistry. Available online: https://rruff.info/enstatite/ display=default/R070550 (accessed on 21 November 2020).

38. El Mendili, Y.; Vaitkus, A.; Merkys, A.; Gražulis, S.; Chateigner, D.; Mathevet, F.; Gascoin, S.; Petit, S.; Bardeau, J.-F.; Zanatta, M.; et al. Raman Open Database: First interconnected Raman-X-ray diffraction open-access resource for material identification. J. Appl. Crystallogr. 2019, 52, 618-625. [CrossRef]

39. Raman Open Database: Information Card for Entry 3500272. Available online: https://solsa.crystallography.net/rod/3500272. html (accessed on 21 November 2020).

40. Raman Open Database: Information Card for Entry 3500271. Available online: https://solsa.crystallography.net/rod/3500271 html (accessed on 21 November 2020).

41. Raman Open Database: Information Card for Entry 3500029. Available online: https://solsa.crystallography.net/rod/3500029. html (accessed on 21 November 2020).

42. Lin, C.-C. High-pressure Raman spectroscopic study of Co- and Ni-olivines. Phys. Chem. Miner. 2001, 28, 249-257. [CrossRef]

43. Kolesov, B.A.; Geiger, C.A. A Raman spectroscopic study of Fe-Mg olivines. Phys. Chem. Miner. 2004, 31, 142-154. [CrossRef]

44. Weber, I.; Böttger, U.; Pavlov, S.; Jessberger, E.; Hübers, H.-W. Mineralogical and Raman spectroscopy studies of natural olivines exposed to different planetary environments. Planet. Space Sci. 2014, 104, 163-172. [CrossRef]

45. Catalano, M.; Bloise, A.; Pingitore, V.; Cazzanelli, E.; Giarola, M.; Mariotto, G.; Barrese, E. Synthesis and characterization of Zn-doped enstatite. Appl. Phys. A 2015, 120, 175-182. [CrossRef]

46. Zucker, R.; Shim, S.-H. In situ Raman spectroscopy of MgSiO3 enstatite up to 1550 K. Am. Miner. 2009, 94, 1638-1646. [CrossRef] 